NBER WORKING PAPER SERIES

\title{
RELIGIOUS EXTREMISM: THE GOOD, THE BAD, AND THE DEADLY
}

\author{
Eli Berman \\ Laurence R. Iannaccone \\ Working Paper 11663 \\ http://www.nber.org/papers/w11663
}

\author{
NATIONAL BUREAU OF ECONOMIC RESEARCH \\ 1050 Massachusetts Avenue \\ Cambridge, MA 02138 \\ September 2005
}

This work was supported in part by grants from the Mercatus Center at George Mason University and the Project on Religion, Political Economy, and Society at Harvard University and National Science Foundation grant \#0214701 through the National Bureau of Economic Research. Early versions of this paper were presented at the 2002 Meetings of the European Public Choice Society, and at workshops at George Mason University, the Australian Defence Force Academy, and Marquette University. We are indebted to colleagues at these institutions for their comments and suggestions, and to Charles Rowley and the other participants of the Conference on the Political Economy of Terrorism. The views expressed herein are those of the author(s) and do not necessarily reflect the views of the National Bureau of Economic Research.

(C)2005 by Eli Berman and Laurence R. Iannaccone. All rights reserved. Short sections of text, not to exceed two paragraphs, may be quoted without explicit permission provided that full credit, including $\odot$ notice, is given to the source. 
Religious Extremism: The Good, The Bad, and The Deadly

Eli Berman and Laurence R. Iannaccone

NBER Working Paper No. 11663

September 2005

JEL No. Z12, H56, H41, K4

\title{
ABSTRACT
}

This paper challenges conventional views of violent religious extremism, particularly those that emphasize militant theology. We offer an alternative analysis that helps explain the persistent demand for religion, the different types of religious that naturally arise, and the special attributes of the "sectarian" type. Sects are adept at producing club goods — both spiritual and material. Where governments and economies function poorly, sects often become major suppliers of social services, political action, and coercive force. Their success as providers is much more due to the advantages of their organizational structure than it is to their theology. Religious militancy is most effectively controlled through a combination of policies that raise the direct costs of violence, foster religious competition, improve social services, and encourage private enterprise.

\author{
Eli Berman \\ Department of Economics, 508 \\ University of California, San Diego \\ 9500 Gilman Drive \\ La Jolla, CA 92093 \\ and NBER \\ elib@ucsd.edu \\ Laurence R. Iannaccone \\ Mercatus Center \\ at George Mason University \\ 3301 N. Fairfax Dr., Ste. 450 \\ Arlington VA 22201 \\ larry@econzone.com
}




\section{Introduction}

At first glance, the link between religious extremism and terrorism seems obvious. Religious extremists are willing to murder because they embrace theologies that sanction violence in the service of God. They have no sympathy for their victims, because they view those victims as enemies of God. And they readily sacrifice their own lives because they expect huge and immediate afterlife rewards in return form "martyrdom.",

But upon closer examination, theological explanations raise more questions than they answer. If theology is so important, why are most terrorist organizations not religious? And if afterlife rewards are key, why has a nonreligious group - the LTTE "Tamil Tigers" - been responsible for more suicide attacks than another other organization? Why is suicide bombing associated with all sorts of theologies but just one style of religious organization (best described as "sectarian")? And why do most militant sects devote much of their energy to benign and noble activities, such as running schools, health clinics, and social services agencies?

To answer those questions we propose an approach grounded in economics and informed by scholarship on the internal organization of religious sects. This approach reflects our conviction that one cannot comprehend the suicidal zealot apart from the selfsacrificing saint - not because the two share a moral equivalence, but rather because the internal logic and social foundations of religious extremism are much the same, whether the extremists' goals are good, bad, or deadly. ${ }^{2}$

Our analysis follows the lead of Adam Smith who laid the foundation for the economic analysis of religion in 1776. In The Wealth of Nations, Smith (1965, pp. 740766) argued that self-interest motivates clergy just as it does secular producers; that market forces constrain churches just as they constrain secular firms; and that the benefits of competition, the burdens of monopoly, and the hazards of government regulation are as real for religion as for any other sector of the economy.

Smith's insights were overlooked for more than two centuries, by sociologists, psychologists, and anthropologists who approached religion as decidedly non-rational behavior, and by economists who ignored religion altogether. Indeed, the overwhelming 
majority of 19th and 20th-century social scientists dismissed religious institutions as a dying vestige of our primitive, pre-scientific past. But contemporary scholars have returned to Smith's insights. Viewing religious behavior as an instance of rational choice, rather than an exception to it, economists have analyzed religious behavior at the individual, group, and national levels. Sociologists are doing much the same, and many now speak of rational choice and market models as the "new paradigm" for the study of religion (Warner 1993).

Because extremist groups constitute just one segment of the religious marketplace, and because that segment cannot be understood in isolation, we begin by examining the overall market for religion. Section 2 focuses on the demand for supernaturalism - the defining characteristic of religion - and section 3 considers features that distinguish the market for supernaturalism from standard markets. In section 4 we discuss how problems of credibility and free-riding give rise to sectarian religions. Section 5 explains why sects are adept at joint production - providing social services, insurance, political action, and other secular goods, together with the spiritual goods that we usually associated with supernaturalism. Section 6 considers the conditions under which violence becomes yet another "joint product" of religious sects, and section 7 turns to policy implications, especially as they apply to Radical Islam.

Among the policy-relevant themes, two merit special note: First, academics, journalists, and governing officials can best understand religious commitment - even its more extreme manifestations - by viewing it as rational (normal, reasonable) behavior. And second, the effects of government intervention are, if anything, more pernicious in the realm of religion than in the realm of commerce. To label religious extremism the product of ignorance, coercion, or psychopathology is to foster misunderstanding. To combat extremism (as opposed to extremist violence) with the powers of the state is to invite conflict if that extremism represents a widespread unmet demand for some set of services. To support "good" religion while repressing "bad" religion is to invite violence. 


\section{Toward an economic theory of supernaturalism}

The economics of religion is characterized by an approach rather than a domain of study. As with other applications of economics theory (Becker 1976, p. 5), it rests upon "the combined assumptions of maximizing behavior, market equilibrium, and stable preferences used relentlessly and unflinchingly." The approach thus views people as rational religious consumers. With an eye toward costs and benefits, they choose how extensively to participate in religion and what religion (if any) they will embrace. Over time they may substantially modify their religious choices and, hence, their religious activities. They may do so even if their tastes, norms, or beliefs do not change. Indeed, the economic approach views most behavior as rational responses to varying prices, incomes, skills, experiences, technologies, and endowments.

Similar assumptions apply to religion's supply side. Religious producers maximize membership, net resources, government support, or some other basic determinant of institutional wellbeing. The actions of churches and clerics (or denominations and rabbis) are thus modeled as rational responses to the constraints and opportunities found in the religious marketplace.

The combined actions of religious consumers and religious producers form a religious market, and as in other markets the consumers' freedom to choose constrains the producers of religion. A "seller" (whether of automobiles or absolution) cannot long survive without the steady support of "buyers" (whether money-paying customers, duespaying members, contributors and coworkers, or governmental subsidizers). Consumer preferences thus shape the content of religious commodities and the structure of the institutions that provide them. These effects are felt more strongly where religion is less regulated and competition among religious firms is more pronounced. In a highly competitive environment, religions have little choice but to abandon inefficient modes of production and unpopular products in favor of more attractive and profitable alternatives. The output mix depends on the supply of substitutes. (So, for example, the growth of the welfare state in Europe and the U.S. has tended to crowd out church-based provision of higher education, medical care, and support for the poor and elderly.) 
As the previous paragraphs suggest, standard economic insights have much to say about religion. The economic theorist can posit a demand for (suitably-defined) religious commodities and jump straight insights about production, consumption, supply, demand, cost, benefit, monopoly, competition, regulation, and laissez-faire. Most contributions to the economics of religion do just this, sidestepping debates about the fundamental nature of religion, the sources of individual faith, and the structure of religious institutions (Iannaccone 1998).

A different approach is needed, however, to construct a general theory of religion with relevance for many religions, in many times, cultures, and places. To explain the fundamental features of religious practice, including those we associate with extremism, religious commodities must be distinguished from all other commodities, and the demand for religion must be distinguished from all other demands.

The following paragraphs review a theory of religion that Iannaccone develops more fully in a forthcoming book. The theory is by no means complete. It does, however, get beneath the standard "givens" of economic analysis, working from more basic assumptions about the physical world and human nature. It defines religion, magic, and supernaturalism in terms that are broad yet amenable to economic analysis. ${ }^{3}$ It accounts for the universality of supernaturalism, the differences between religion and magic, the appeal of specific religious doctrines, and the tendency for science and technology to displace magic more readily than religion. (The body of this paper restricts its focus to religion; see the appendix for a discussion of magic.) Thanks to the meticulous work of anthropologists, sociologists, and historians, we can confirm many of the theory's predictions, drawing from a wealth of historical and ethnographic data concerning "primitive," ancient, and non-Western cultures.

\section{Scarcity, Rationality, and the Demand for Supernaturalism}

The theory presumes a human tendency to identify most everyday phenomena as natural or normal. The SUPERNATURAL refers to forces or beings beyond or outside this natural order, which can suspend, alter, or ignore the normal flow of events.

The theory also presumes scarcity and rationality. In the beginning, in the end, and everywhere in between, there is no such thing as a free lunch. Yet humans do not 
simply accept scarcity. The pressures of survival and the powers of their minds motivate people to strive for longer, more comfortable, and more meaningful lives. Most efforts fail, but some succeed spectacularly, as with the development of agriculture, writing, law, and art, or in more recent times engineering, modern medicine, computing, and constitutional democracy. Each of these magnificent inventions may be viewed as a technology to expand our "opportunity sets" and push back the limits of scarcity.

Against this background, supernaturalism emerges as an alternative technology a natural, understandable, and perhaps even fully rational attempt to enhance individual and collective welfare. Supernaturalism posits the existence of mystical powers that transcend the usual technological constraints and physical limits of everyday life. If it is possible to influence, harness, or benefit from such powers, then the supernatural provides yet another way to combat scarcity. To be sure, its existence and efficacy eludes positive proof - a fact that did not escape the notice of ancient "primitives" any more than it has that of modern scientists. But uncertainty cannot quench its underlying attraction, for by definition the supernatural holds forth the prospect of otherwise unattainable rewards.

\section{Demand for the supernatural can be viewed as a reasonable response to} inescapable scarcity, insatiable wants, and irrepressible hope. Supernaturalism confronts humans with the broadest form of Pascal's Wager (Pascal 1910, §233). For anyone willing to grant the supernatural some probability of existence, it almost certainly makes sense to try at least one thing that one would not otherwise do - offer prayers (as even most atheists admit to saying), practice rituals, embrace beliefs, wear charms, worship, meditate, study, dance, chant, conjure, or sacrifice. As with "normal" behavior, these acts of religion and magic increase one's expected utility wherever their costs are lower than their postulated benefits times the subjective probability that the benefits will, in fact, arise. Supernatural investments make sense, not just for the credulous, fanatic, and faithful, but also for the hopeful skeptics and cautious agnostics - anyone who does not know the skies are empty. We thus arrive at a proposition that turns the standard notion of faith on its head:

Rational individuals will seek to understand and influence the supernatural to the extent that they remain uncertain of its NON-existence. 
The point is not to defend supernaturalism, nor discredit it, but merely to emphasize its underlying economic rationale and universal attraction. Neanderthal and Cro-Magnon man left cave paintings, burial sites, and carvings that virtually all archeologists take as proof of religious beliefs. Every historic culture has left a rich record of supernatural beliefs and practices - in temples and totems, traditions and texts, and art and administration. Supernaturalism is no less universal in the hundreds of preliterate societies observed and catalogued by 19th and 20th century anthropologists.

Supernaturalism likewise prevails in every society of today's developed world. Although Americans seem to hold the record for religiosity, with more than $95 \%$ professing belief in "God or a Universal Spirit," the supposedly secular populations of Europe maintain remarkably high levels of faith in supernatural phenomena. In every European country (except the former East Germany), atheists number fewer than fifteen percent of the population (Jagodzinski and Greeley 1997). The resilience of religiosity is nowhere more evident than in Russia, where despite sixty years of state-sponsored atheism, bloody church purges, widespread religious persecution, and pervasive secular indoctrination, only eight percent of the people remained atheistic by 1990 and religious belief was especially widespread among the young (Filatov 1993: 120; Troyanovsky 1991).

The vast majority of people find atheism intellectually demanding and emotionally unsatisfying. One must push well beyond the uncertainty of the agnostic or the inactivity of the apathetic, only to be rewarded with the absence of hope. No wonder the children of atheists are more likely to abandon their parents' beliefs than are the children of any (other) religion (Stark and Bainbridge 1985: 47-48).

An economic perspective which treats the supernatural as a class of goods thus helps us to understand one of the great predictive failures in the history of the social science: the failure of secularization theory. For centuries, scholars have confidently, and incorrectly, predicted the immanent demise of religion. With powerful prose, but no real proof, Hume, Comte, Marx, Freud, the Huxleys, and other influential intellectuals, pronounced religion a dying vestige our primitive, pre-scientific past (Stark, et al. 1996). Within academia, the media, and most public discourse, this received wisdom sustained a large body of stylized facts. For example: that religion must inevitably decline as science 
and technology advance; that individuals become less religious and more skeptical of supernaturalism as they acquire more education, particularly more familiarity with science; and that most members of deviant "cults" and fundamentalist "sects" are victims of indoctrination or abnormal psychology (from trauma, neurosis, or unmet needs). In contrast, decades of empirical research, using methods that range from cross-cultural comparisons to cross-sectional surveys, leave no doubt that these generalizations are simply false (Greeley 1989; Hadden 1987; Stark and Bainbridge 1985). Throughout the world - in Latin America, India, Africa, Europe, the Middle East, formerly communist countries, and the United States - religion continues to flourish, especially its more fundamentalist variants.

In short, the demand for supernaturalism is as basic and irrepressible as the wants it seeks to satisfy.

\section{Meeting the demand: entrepreneurs of the supernatural}

What many demand, others will gladly supply. The consumers' hope for otherwise unobtainable payoffs provide ample opportunities for producer profit. Markets for supernatural goods and services thus develop as naturally as other markets, and sooner in cultural history.

Self-interest and other standard economic forces promote professionalization. Entrepreneurs of the supernatural arise to exploit the gains from trade, specialization, and entrepreneurship. These would-be priests, prophets, and seers fan to flame the sparks of faith. Whether prompted by conviction or the lure of profit, prestige, and power, their activities promote belief and shape its form. Specialization leads, in turn, to institutionalization and product differentiation. Groups of religious entrepreneurs establish firms and franchises, offering distinctive services, terms of trade, apprenticeship programs, rites of initiation, and rules of membership. The organizational features we associate with religion in contemporary Western countries, including congregations, denominations, and clergy, are strictly analogous to those of secular industries. 
Yet a standard business model does not apply. Markets for the supernatural have special features, which trace back to the unique character of their underlying technology. Three deserve emphasis:

First, the market is naturally competitive, with few barriers to entry or imitation, and modest returns to scale. The range of promised products is as broad as the imagination allows and as deep as a customers' willingness to pay. So the incentive to enter is strong. Backed by coercive power, a single religious firm may dominate the market for "legitimate" religion, but diversity and competition almost always persist in an underground economy (as illustrated by Biblical Israel's failure to root out pagan worship or the Medieval Catholic Church's inability to eliminate witchcraft, heresy, and sect movements).

Second, the market offers a uniquely wide range of products. In principle and practice, no desire, however large, small, abstract, or specific lies beyond the range of the supernatural. People will invoke the supernatural for everything. Individually, they will pray (and sacrifice, and chant, and meditate) not only for salvation in the hereafter, but also for physical health, emotional support, information and advice, prosperity, good fortune, favorable weather, protection from enemies, plentiful harvests, life-after-death, romance, revelations, and even good sex. ${ }^{4}$ Collectively, they will also petition the supernatural for peace, prosperity, domestic tranquility, victory in battle, and a bright future. And those in positions of power will, regardless of their personal beliefs, publicly invoke the supernatural to motivate (or terrify) their subjects, maintain loyalty, legitimate their power, and reinforce the prevailing social order. There is thus no logical limit to the size or scope of rewards that humans will seek through supernatural means. ${ }^{5}$ Jeffersonian Deists and Unitarian preachers may proclaim a distant God, who forswears miracles and magic, but rank-and-file believers the world over seem happy to seek every conceivable blessing - material or spiritual, miraculous or mundane, specific or general, and hereand-now or by-and-by.

Third and critically, the market must address problems of information and uncertainty. The existence and efficacy of supernatural technologies remain always a matter of faith. The prospect of otherwise unobtainable rewards (including eternal life, peace on earth, and unending bliss) is tied to tremendous uncertainty. In the language of 
economists Darby and Karni (1973), religion offers the ultimate in "credence goods," because no amount of experience (this side of death) suffices fully to evaluate its quality

and efficacy. Insights from the economics of uncertainty help us understand the activities and institutions that arise in response to this dilemma. In particular, two different strategies for managing risk - diversification and specialization - arise in both secular and religious markets. As we shall see, the different strategies lead to different forms of religious organizations (inclusive versus exclusive) specializing in different types of products and different patterns of practice.

\section{Organizational forms: denominations and sects}

Within the religious marketplace there naturally arise different niches, not all of which provide equally intense experiences. Some religious traditions, notably Judaism, Christianity, and Islam, have a much stronger communal orientation than others, such as Buddhism and Hinduism. Within each religious tradition, moreover, some firms maintain rigorous systems of shared beliefs and morality, whereas other firms demand very little. It is the former that we label "extremists" (or "sects," "cults," and "fundamentalists"); the latter are more known as "moderates," "liberals," or "mainstream churches."

Traditional academic theories of religion have no way to explain the persistence of extremist groups except to view their adherents as victims of ignorance, coercion, deception, or psychopathology. Economic theory does better. Without resort to irrationality, it explains on-going demand for supernaturalism, distinguishes magic from religion, predicts their chief differences, and, as we shall see, accounts for religious extremism (sects).

Risk: To better understand the appeal of group-oriented religion, and to see how this leads in turn to religious extremism, let us return to the problem of religious risk. The dilemma confronting religious consumers is analogous to that which confronts usedcar buyers. Product quality is difficult to assess, even after purchase and use, and this tempts sellers to overstate the value of their merchandise or disguise its flaws. Not 
wishing to be cheated, buyers demand guarantees, seek information from third parties, or investigate the seller's reputation. Sellers are thus motivated to provide, or at least appear to provide, proof that their claims are true. Because the logic of this argument applies quite generally, we can predict the emergence of religious institutions and arrangements designed to reduce fraud and increase information.

Examples are not hard to find. Testimonials are commonplace in religion and, predictably, are more common in those variants that place greater emphasis on material blessings. Testimonies are more likely to be believed when they come from a trusted source, such as a personal acquaintance or a respected figure. They are especially credible when testifiers have relatively little to gain (or, better yet, much to lose) from having their claims heard and believed. This helps to explain why the character of religious activity is so often collective and the structure of religious organizations is so often congregational. Fellow members are more trustworthy than strangers. They also have less incentive to overstate the benefits of the religion than do members of the clergy, whose livelihood depends on a steady stream of "sales." The clergy, in turn, are more persuasive when they do not benefit materially from their followers' faith or when they receive low salaries relative to their level of training.

Economic theory thus explains several distinctive features of religious institutions in terms of their ability to reduce fraud. These include: a minimal professional staff whose financial compensation is low or independent of customer payments; heavy reliance on part-time and volunteer workers (and thus reliance on payments of time and service rather than money); a congregational structure, which limits the need for full-time professionals and provides a source of credible product endorsements; and collective activities, which provide continuous assurance through the enthusiasm, devotion, conviction, and testimony of fellow members.

Free-riders: Unfortunately, the same congregational structure that works to reduce the risk of fraud, thereby making religion more compelling and attractive, also makes it more vulnerable to "free-rider" problems. Such problems arise wherever individuals find it possible to reap the benefits of other people's efforts without expending a corresponding effort of their own. 
One need not look far to find examples of anemic congregations plagued by freeriding - a visit to the nearest "liberal" Protestant church usually will suffice. In theory and practice, however, it is the most communally-oriented groups that are most susceptible to free-riding. Kanter (1973: 157-158) documents the commitment problems that plagued most nineteenth century communes and quotes Charles Guide's observation that "these colonies are threatened as much by success as by failure ... [for] if they attain prosperity they attract a crowd of members who lack the enthusiasm and faith of the earlier ones."

Sacrifice and Stigma: Costly demands offer a solution to the dilemma (Iannaccone 1992; 1994). The costs are not the standard costs associated with the production or purchase of secular commodities. Rather, they are apparently gratuitous costs that demand sacrifice and invite stigma: burnt offerings, which destroy valued resources; distinctive dress and grooming that bring ridicule or scorn; dietary and sexual prohibitions that limit opportunities for pleasure; restrictions on the use of modern medicine or technology. The list goes on. Such costs are present to some degree in all religions, but they are especially pronounced in the groups we label "extremist."

Costly demands mitigate the free-rider problems in two ways. First, they create a social barrier that tends to screen out half-hearted members. No longer is it possible simply to drop by and reap the benefits of attendance or membership. To take part, one must pay a price, bearing the stigma and sacrifice demanded of all members. Second, they increase the relative value of group activities, thereby stimulating participation among those who do join the group. Social stigmas make it costly (or even impossible) to engage in activities outside the group, and as the price of external activities rises, the demand for internal substitutes increases. To put the matter crudely: a comprehensive ban on dances, movies, gambling, drinking, and "worldly" friendships can turn a church social into the highlight of the week.

Extremist groups thus survive and flourish. Their costly strictures induce high levels of commitment and participation; and, strange as it may seem, many members come out ahead, even after taking full account of their social and economic losses. The required tradeoff is most likely to benefit people with limited secular opportunities (due, for example, to limited education, low wages, unpleasant jobs, or low social status). 
People with greater secular opportunities (and those who simply attach less faith or value to the supernatural) will prefer less demanding groups, even if it these groups provide fewer rewards. Their behavior represents an alternative risk-reducing strategy, tantamount to investing in assets with lower but more certain rates of return. ${ }^{6}$

Denominationalism: The journey through risk, collective action, free-riding, and costs thus leads to theory of religious denominationalism with testable implications. The theory classifies religious groups according to the extent to which they limit the consumption opportunities of their members. Moreover, it predicts the emergence of a denominational continuum within any major religious tradition, be it Christian, Jewish, Moslem, Buddhist, or Hindu. Toward one end of the continuum, we expect to find "extremist" groups that demand very high levels of sacrifice. Toward the other end, we expect to find "lenient" groups that demand very little of their members. If the theory is correct, then groups that demand similar levels of sacrifice will display similar social characteristics despite their differences in organization, history, and theology. Thus, the high-cost groups of any religious tradition will tend to be exclusive, strict, small (at the local level), suspicious of other groups, and critical of secular society. Members will learn to fully embrace the group's distinctive lifestyle, devoting their resources to the group's activities and goals, or else face penalties, up to and including expulsion. As a result, these high-cost groups will also maintain tighter social ties, as shown for extreme Christian sects in the U.S. by Iannaccone (1992). In contrast, low-cost groups will tend to be inclusive, lenient, tolerant of secular values, and open to loosely affiliated members, while providing less cooperatively provided services.

That predicted pattern is in fact consistent with the observations of generations of scholars. The empirical regularities associated with different "types" of religious groups have fascinated sociologists of religion for nearly a century. Following the pioneering work of Ernst Troeltsch (1931) and Max Weber (1963), sect is the generic term most often applied to exclusive groups, whereas inclusive groups are called churches. There exists a mountain of research documenting the social characteristics of religious groups and their members and confirming the correlation among various institutional and individual characteristics. On the other hand, scholars have been at a loss to explain why these different characteristics hang together. 
Against this backdrop, the economic theory of denominations is a major step forward. Mainstream "churches" and extremist "sects" emerge from it as analytically distinct modes of religious organization rather than ad hoc descriptive categories, and the empirical correlates of sectarianism (including strict behavioral standards, dramatic conversions, high levels of religious participation, resistance to social change, lower-class and minority appeal) emerge as formal consequences of a high-cost/high-commitment strategy. (See Iannaccone 1988; 1992; 1994 for details.) A single theory thus suffices to explain (and predict) numerous empirical insights about religious organizations and their members.

\section{Joint production: the good}

High-cost sectarian religion appeals to many people because it provides a setting in which normal, but unsatisfied, wants can be met. Extremist "sects" are faith-based communities, dedicated to the production of communal goods and to the pursuit of communal goals. To miss this point, as do many scholars and most journalists, is to miss the essence of sectarianism and buy the rhetoric of its critics. Leaning heavily on words like "angry" and "intolerant," the standard accounts portray sect members as militant fanatics fighting backward-looking campaigns against the enlightened forces of liberal, progressive modernism. The truth is far different and far less frightening.

Sectarian movements flourish because they provide their members hope for the future, benefits for the present, and insurance against misfortune. They assist those who suffer financial setbacks and ill health. Their social networks help members form joint business ventures, establish long-term friendships, and find suitable marriage partners. As Adam Smith realized, they also provide information about an individual's reliability and credit-worthiness, which economically disadvantaged people may otherwise have trouble signaling to financial institutions, prospective employers, and the society at large (Smith 1965). Sects help parents socialize their children; their concern for "family values" is no coincidence. Combine the typical sect's comprehensive behavioral guidelines with its members' high levels of commitment and participation. Add 
extensive monitoring and sanctions, both formal and informal. One arrives at a very effective means of constraining opportunistic behavior and transmitting values to children (Iannaccone 1995).

Why are sectarian groups so good at providing concrete goods and services? Recall that the success of their core business rests upon their capacity to maintain credibility and minimize free riding. These are the very attributes that facilitate mutual insurance, philanthropy, and community action. Credibility is also critical in business dealings, trading networks, and social service provision. Thus, we should not be surprised to see sectarian communities successfully engaged in these activities, especially where poor government or civil disorder undermines the secular provision of schooling, health care, poverty programs, property rights, financial services, police protection, and so forth. ${ }^{7}$

Case studies and survey data provide strong support for all these claims. Sectarian denominations are more supportive of community members, as evidenced by the high proportion of income members of U.S. Christian sects donate to their own communities (Iannaccone, 1992). This mutual support has many concrete benefits. In America, for example, adolescents raised in sectarian denominations manifest lower levels of most "deviant” behaviors including drug use, smoking, drinking, and criminal activity (Bock, et al. 1987; Stark and Bainbridge 1998). Sect members who marry within their religion have substantially lower divorce rates than couples from different, or less sectarian, religious backgrounds (Lehrer and Chiswick 1993). Moreover, a large body of empirical research, published in numerous medical and psychological journals, links high levels of religious faith and participation to improved mental and physical health. Religiosity in general and sect membership in particular, seems to increase life satisfaction, promote healthy behaviors, and insulate people against emotional and physical stress (Ellison 1991 and; 1993).

The situation is much the same in Judaism and Islam. Ultra-Orthodox Jews in Israel and throughout the world have a much more extensive mutual support network than do less observant denominations within Judaism (Berman 2000). From Egypt and Palestine to Pakistan, Afghanistan, and Indonesia, radical Islamist groups have enjoyed broad support - especially among the poorer segments of society - because they are 
major suppliers of mutual aid and social services. Chen (2003; 2004), for example, demonstrates that Indonesian Muslims who suffered declines in income do to the currency crisis increased their participation in Islamic mutual insurance networks, and their participation in Koran study groups.

The social, economic, and political role of sectarian organizations is especially great in contemporary Islamic countries, where external resources and internal conflicts have combined to enhance the power of mullahs, mosques, and madrashahs. Thus, as Fritsch (2001) notes, the "near collapse of public education in Pakistan and Afghanistan and the corresponding rise in influence of the madrashahs - are critical legacies of more than two decades of Cold War proxy battles." Radical Islam flourished in Afghanistan when external funding poured in to support Islamist insurgency against the Soviets. When the Soviets retreated and the U.S. suspended most of its financial support, but "militant Muslims eagerly stepped into the vacuum" providing, among other things, free education, room, and board to the young boys it trained as Taliban. The Hizbullah in Lebanon is another example of a radical Islamic movement which greatly expanded the size and religiosity of its following by channeling foreign funds (from Iran) into a network of schools, clinics and welfare organizations.

Outside funds can also boost the extremism of sectarian groups, and not merely by placing more resources in the hands of "fanatical" leaders. Recall that sects employ sacrifice to screen out free riders and enhance team effort. Funding upsets this balance unless required levels of sacrifice are raised to offset the external subsidy. Berman (2000) has studied this dynamic among the Ultra-Orthodox in Israel, where three decades of increasingly generous support from the Israeli government and from Jews abroad have led to increasingly deviant behavioral norms. Ultra-Orthodox men have stretched out their years of religious studies (and thereby reduced their lifetime labor supply) by a decade, while their wives have increased lifetime childbearing by an average of two children - and this while Israeli Jews have generally reduced childbearing.

We must remind the reader the majority of services provided by radical religious groups are utterly benign. They help to feed the hungry, aid the sick, educate children, and house the poor. To see those activities as mere façade is to misunderstand the sectarian raison d'être. Critics who denounce the charitable acts of Hamas and 
Hezbollah as a public relations ploy are quite wrong. ${ }^{8}$ But so too are supporters who argue that the good deeds and religious goals of the "true" believers are wholly separable from the deadly crimes of a militant minority.

\section{Joint production: politics and violence - the bad and the deadly}

To reiterate, sects are high-powered religious organizations, run by credible leaders and peopled by active members carefully screened for commitment. Sad to say, these same institutional attributes are also keys to the successful "production" of organized violence, especially clandestine violence. A soldier running toward a target under fire must be absolutely certain that his comrades are "covering him" with simultaneous fire toward the target. A terrorist's worst nightmare is the comrade who chickens out, sells out, or proves incompetent. A terrorist working within a sect can thus sleep a little easier. The leaders have established their reputation for honesty, and so are unlikely to sell out, and the comrades have been carefully selected for commitment to the cause (Berman 2003). Moreover, the sect's diverse bundle of social services reinforces the commitment of comrades. Who would defect from the very organization that feeds, educates, and protects one's family?

It is thus no coincidence that groups like Hamas, Hizbullah, and Taliban have "diversified" into the business of violence. By virtue of its sectarian structure, Hamas is a more effective terrorist organization than the more experienced, but secular, Fatah or the Islamic Jihad, which shares the theology of Hamas but lacks its social service network (Berman 2003; Berman and Laitin 2005). The Hizbullah is another example of a hybrid organization, jointly providing supernatural services, education and social services, and organized violence. The Taliban are a special case. They diversified out of supernatural services into providing the most basic of services - law and order - in the form of protection from the arbitrary violence of warlords. They then expanded into securing smuggling and trade routes and into limited social service provision and, with some outside subsidies, formed a militia effective enough to defeat much more experienced Mujahhedin for control of Afghanistan, an astounding accomplishment for a 
group of former seminary students (Berman 2003; Rashid 2002)! Chen (2004) finds evidence suggesting that Indonesian Islamists may also have a hybrid aspect, as communities with high rates of participation in Islamic mutual insurance tend to also have high rates of communal violence.

Our argument thus differs both from those who discount the role of religion in contemporary terrorism and from those who emphasize the militant theology of certain religious traditions. Religion does contribute to the efficacy of certain terrorist groups, but not primarily because of their militant "worldviews" or "theologies of hate." is an instructive case. It existed for decades as the Muslim Brethren in Palestine, espousing a doctrine that opposed violence against the State of Israel and instead emphasized personal piety and political Islam (Mishal and Sela 2000; Schiff, et al. 1990). The shift toward violent demonstrations and terrorism did not occur until the first Palestinian uprising, when the secular nationalists threatened to undermine Hamas' popular support. This is typical of religious extremists. Their militancy varies dramatically over time, even as their underlying sectarian traits remain fairly stable. Moreover, they prove remarkably adept at reworking their theology, and even reinterpreting their most sacred texts, so as to justify their changing orientations. For extensive evidence, see the volumes of the Fundamentalism Project, edited by Marty and Appleby (1991).

If militant theology is more often consequence than cause of a militant orientation, what leads religious groups toward militancy in the first place? Here we part company with those who emphasize social and economic factors to the exclusion of religion, and with those who do the reverse. ${ }^{10}$ Religious groups chose violence to improve the lot of their institutions and constituents, by resisting repression and gaining political power.

Church, State, and Politics: Throughout history, religious groups have played major roles in political systems. The reasons are manifold, including the tendency for secular regimes to seek the legitimacy associated with sacred authority and the corresponding tendency for religious regimes to seek the legal and financial support of government. In repressive regimes, places of worship may also become the safest places 
for open political discourse, and religious networks provide ideal bases for political organization. We see this today in many Middle Eastern countries, but it was also the case in Eastern Europe under communism. Moreover, because the clergy must maintain their credibility as salesmen of the supernatural, they are less likely to be corrupted than the typical politician, especially in political systems with weak legal institutions. Credibility and perceived resistance to corruption are strong electoral assets for religious leaders, as is seen in both Palestine and Israel.

So why should we worry about political-religious parties? First, to reiterate the discussion of the previous section, sectarian religious groups enjoy a comparative advantage in certain forms of organized violence. The moment a sect enters the political arena, the stakes associated with winning and loosing become much higher, and hence its incentive to employ violence increases. Iran's Islamic revolution is just one example of this process. Second, because religious groups almost always use their political power to repress religious competitors, political activism on the part of some groups virtually guarantees the mobilization of all religious groups, further increasing the odds that at least some will resort to violence.

We can best appreciate the dangers of political-religious parties by reviewing a centuries-old debate between David Hume and Adam Smith (and in so doing reminds us that violent religious extremism is nothing new). Writing in an era well-acquainted with the bloodshed of the Reformation and religious violence of the English civil war, Hume (1989, pp. 135-136) offered an economic interpretation of fanaticism's cause and remedy. In essence, he argued that religious laissez-faire generates powerful negative externalities, as religious suppliers promote superstition and hostility toward the members of all competing religions, leading ultimately to civil strife and political instability.

Hume's solution is a state-funded established religion, precisely because it "bribe[s] the indolence" of the clergy, turning them into government-paid civil servants with minimal incentives to craft products that excite the general population.

Smith disagrees. Despite quoting Hume at length, and accepting Hume's premise, he utterly rejects his conclusion. Yes, says Smith (1965, p. 741), the clergy of an established church will give "themselves up to indolence" and will neglect "to keep up the fervour of faith and devotion in the great body of the people." And, yes, religious 
laissez-faire will stimulate the clergy's self-interested "industry and zeal," leading them to "use every art which can animate the devotion of the common people" and encouraging numerous sects to enter the religious market and vigorously compete for members. But in the end, it is this vibrant, unregulated religious market that most benefits the state, the general populace, and religion itself.

Had each European government not enlisted the aid of a single sect (and returned the favor by suppressing all other competing sects), there would have been "a great multitude of religious sects." Competition would then induce moderation, rather than the furious, fanatical violence envisioned by Hume:

The interested active zeal of religious teachers can be dangerous and troublesome only where there is, either but one sect tolerated in the society, or where the whole of a large society is divided into two or three great sects; the teachers of each acting by concert, and under a regular discipline and subordination. But that zeal must be altogether innocent where the society is divided into two or three hundred, or perhaps into as many thousand small sects, of which no one could be considerable enough to disturb the publick tranquillity. The teachers of each sect, seeing themselves surrounded on all sides with more adversaries than friends, would be obliged to learn that candour and moderation which is so seldom to be found among the teachers of those great sects, whose tenets [are] supported by the civil magistrate. (Smith 1965, p. 745)

Theory may not suffice to validate Smith's reasoning over Hume's, but subsequent history provides overwhelming evidence of the moderating effects of a truly competitive religious market. By virtual of constitutional law, U.S. government cannot fund religions, favor one religion over another, nor discriminate based on religion. America was the world's first laissez faire religious economy, and as Tocqueville and many other 19th century European traveler noted, the result was exceptional levels of religious participation, an abundance of religious sects, and very little religious conflict (Finke and Stark 1992, pp. 17-20, 39-40). ${ }^{11}$ 
Over the past century most Western countries have radically reduced state support for, and state regulation of, religion. In the process, they have made their nation's religious markets much more open to entry and competition. In nearly all cases, one consequence has been a reduction in the political activities of denominations. Why? Because the stakes have been lowered. Absent the prize of government money and protection from competing groups, a religion finds political activity much less attractive. Also, as Smith emphasizes, open competition also leads to more groups, each of which has less capacity to influence government.

In much of the world, however, and especially in the Middle East, religion and governments remain tightly bound. The leaders of government use religion to enhance their popularity and legitimacy, and religious leaders use political power to direct state resources toward their constituents. Here again, the credence-oriented technology of religious organizations confers important benefits. When used with care, it becomes a powerful tool of organization and persuasion. The leaders of sects are especially adept at "delivering" the votes of members. Note also that repressive regimes, mosques and churches are often the only places where opposition political organization is possible at all. If only for that reason, political Islam is likely to be a going concern for quite a while.

Once in power, religious groups may moderate in order to seek a larger constituency, but the record is mixed and ranges from moderation in Turkey, where church-state separation is enforced by the military, to the ruthless hijacking of a broadbased revolt in Iran. In summary, the efficiency of sectarian groups at politics and organized violence creates the potential for a sect to capture the benefits of political monopoly and then violently repress both political and religious opposition. The weak legal institutions of a nascent state such as Palestine or Iraq would be hard pressed to resist the power of such a sectarian political-religious. 


\section{Policy implications}

Drawing from both the sociology and economics of religion we have argued that it is a serious mistake to view violent religious extremists as pathological drones enslaved by theologies of hate. One gets much more analytical mileage from an approach that treats militant religious extremists as social and political entrepreneurs. (Were it not so, we would face the chilling prospect that safety from religious terrorists could only be obtained at the cost of eradicating the theology or its proponents.) Unlike purely secular actors, they have an advantage at cooperative production technologies that harness the credibility of the clergy and commitment of the members - members who have already accepted the sacrifice of religious prohibitions in return for the benefits of cooperation. Since terrorism and militia activity are extreme forms of cooperative production, sectarian groups can be singularly effective terrorists should they choose that path.

Can policy makers mitigate religious extremism by targeting beliefs and teachings? Sects put tremendous emphasis on dogmatic doctrines and probably cannot maintain their high-cost/high-commitment equilibrium without them. But successful systems of religious belief are by their very nature largely irrefutable. So secular attacks on doctrine and theology antagonize many but convince almost no-one. Indeed, if anyone is equipped to win theological debates with radical sectarians, it is leaders of other religious groups.

Adam Smith's analysis of religious markets lead to the following policy recommendations:

The militant theology of religious radicals is most effectively neutralized by competing theologies, which are in turn most effectively produced by competing religious groups.

An open religious market encourages religious moderation by facilitating the entry of numerous competing religious groups, virtually none of whom can hope to benefit from government control of religion. 
A constitutional commitment to the separation of church and state, including fiscal and legal nondiscrimination, discourages religious militancy by reducing the payoffs associated with religiously-oriented political action.

We can extend this list of policy recommendations by supplementing Smith's analysis with our own analysis of sectarian organizations. Because sects are efficient producers of club goods, they will naturally branch out from their core business as suppliers of the supernatural when secular markets and civil society under-produce collective goods. In the process of providing benign goods and services, a sect acquires the credibility, organization network, and membership base that also facilitate violent collective action. Thankfully, religious organizations almost never benefit from violent action in well-functioning societies. But violence can be very effective where markets, governments, and civil society functions poorly. The ideal solution is, of course, constitutional democracy coupled with a vibrant market economy; but where this goal remains elusive it makes sense to focus more narrowly. Reducing the sectarian comparative advantage in social service production undercuts both the returns to religious violence and the influence that leaders have over the members. Hence,

\section{Religious radicals are less likely to flourish and less likely to embrace} violence when there is strong competition in their non-core markets: including education, health care, poverty programs, and political representation.

Nasser applied this policy in Egypt in the 1950s, when the Muslim Brethren threatened his power. He took not only the conventional approach of locking up the leadership but also nationalized their entire social welfare provision network (Munson 2002). That policy shut down Islamic terrorism in Egypt for more than two decades.

Lest we appear to have arrived at the secularist view that religious terrorism is "really" about economic deprivation, we must remind readers that we are addressing a subtle interaction between religion and economics. As scholars have discovered, most radical Islamic terrorists are relatively well off; they are by no means poor and ignorant people with little to loose (Krueger and Maleckova 2003). ${ }^{12}$ We must distinguish between the overall religious organization, which does indeed gain strength and membership by providing material services to the poor, and the composition and motives of the leadership and most active members. Within these organizations, as in all 
organizations, responsibility and difficult assignments end up in the hands of talented people, most of whom have very good secular alternatives. The pattern has recurred in Palestine, Yemen, Afghanistan, Iraq, and Lebanon during the civil war period. And is it any surprise that when Al Qaeda needed recruits to attend flight school in Florida, they tapped a small group of disaffected expatriate Muslims in Europe students rather than drawing from the thousands of illiterate mercenaries they were training in Afghanistan?

The combination of social service provision, political representation, and nondiscriminatory treatment of religious denominations is not a panacea in the war on terrorism. Yet our analysis suggests that it could in many cases reduce the need for more violent interventions. More importantly, and in contrast to direct military or police-style interventions, this combination of policies has the potential to mitigate the root causes of what looks to be a long confrontation.

\section{Conclusion}

The economic theory of religious extremism is just one piece in a much larger theory of supernaturalism that explains the persistence of belief in the supernatural and the inevitable spread of religious groups along a denominational continuum from lenient "churches" to extreme "sects."

Extremist sectarian groups are high-powered religions rooted in separation from and tension with the broader society. Their heavy demands make it possible to offer unusually great benefits to potential members, particularly those at the margins of society. An economic perspective thus explains how extremist groups can persist and prosper in thoroughly modern societies peopled by perfectly rational citizens.

To equate religious extremism with religious militancy is a serious error (and, in many instances, a political ploy). The ideological and social barriers that separate sect members from other religious groups and from secular society rarely lead to violent conflict. In fact, minority status usually guarantees that sect members lose out in any confrontation with larger powers. 
Conflict and militancy becomes common, however, where the state favors one religious group over another (or there is an expectation that the state will do so after it is established), thereby raising the stakes for all sides. People will take great risks to defend or enlarge their political power, and sectarian groups are well positioned to marshal their resources and members in opposition to their religious-political competitors. Unlike purely secular actors, sectarian groups have an advantage at cooperative production that makes use of the credibility of the clergy and commitment of the members - members who have already accepted the sacrifice of religious prohibitions in return for the benefits of cooperation. The returns to cooperative production of basic social services (education, medical care, law and order) become greater still where secular society under-produces them. Since organized violence is an extreme form of cooperative production, sectarian groups can be singularly effective terrorists should they choose that path to political power.

The economic perspective strikes a somewhat sanguine note, for it suggests that religious freedom offers the best insurance against religious fanaticism. Whereas government regulation and state-sponsored religion encourage sects to fight both church and state, a truly competitive religious market encourages religious tolerance and mutual respect if only as a matter of necessity. U.S. history seems to bear out the wisdom of this policy. U.S. churches never fought over control of the state, apparently church-state separation precluded any possible victory. In the Middle East, the extreme militancy of Islamic groups engaged in struggles over political objectives and political power underscore the peril of the alternative approach.

We do not seek to minimize the threats posed by truly militant religious groups. The well-organized terrorism of Al Qaeda, Islamic Jihad, Hamas, and other Muslim extremists are a threat of global proportions. Violent conflicts between India's Sikhs, Moslems, and Hindus have threatened the political and social stability of the world's largest democracy. The bombings and murders attributable to Ulster Protestants and IRA Catholics made a war zone of regions that should, by all rights, be places of peace and prosperity. But taking a cue from Adam Smith, scholars should examine these true instances of religious militancy and ask how much violence should be attributed to the religious-political environment rather than the religion itself. Genuinely violent sects 
tend to arise in countries where the civil government has suppressed religious freedom, favoring one form of religious expression over all others. Within these environments, a disfavored sect is strongly motivated to oppose the government, despise the established religion, and covet the privileges that come with state support. Those principles can usefully inform the policies of many countries, most especially those in the Middle East. 


\section{Appendix: religion versus magic}

Of all the factors that promote product differentiation and sub-market formation in the market for the supernatural, none are more striking than those that separate religion from magic. These two conceptions of the supernatural imply two different modes of interaction, leading to differences in form, content, outcomes, and organizational structure.

My use of the words "magic" and "religion" parallels that of $19^{\text {th }}$ century anthropologists. Religion consists of beliefs, practices, and institutions that relate to one or more supernatural beings. The one great God of Israel, the many small gods ancient Greece, the ancestral spirits of Chinese Shinto worshippers, and, I suppose, the ghost of Christmas past all qualify as supernatural beings. At a minimum, every such being possesses consciousness and desire in addition to superhuman powers (Stark and Bainbridge 1987: 82). Magic, by contrast, consists of beliefs, practices, and institutions that concern impersonal supernatural forces or the impersonal manipulation of supernatural beings. When astrologers cast horoscopes, or athletes carry good luck charms, or fortune-tellers read the future from a deck of cards, their activities qualify as magic. Most "New Age religion" likewise qualifies as magic, be it crystals, pyramid power, palmistry, or mystical auras. ${ }^{13}$ Insofar as humans cannot help but imagine the supernatural with reference to the natural, the tendency to distinguish between personal and impersonal agency is understandable and, probably, inevitable.

The economics of magic versus religion hinges on the fact that methods of magic and religion are inherently different. The former involve supernatural production; the latter, supernatural exchange. Production is impersonal; specific inputs, manipulated in specified ways, yield specific outputs. Exchange is, by contrast, interpersonal, a process of communication and bargaining that involves character no less than competence. (Here again, the magic-religion distinction embodies a natural difference, corresponding to the two ways humans overcome scarcity in the natural world.)

The logic of production traps magic. On the one hand, magicians must promote themselves as masters of the supernatural. On the other hand, they cannot properly account for their failures, except to emphasize their personal limitations or the limitations of the forces they control, neither of which plays well in the market. No magician can fully escape the dilemma: impersonal forces do admit testing, and effective methods for their control should work on demand. True magicians should succeed here and not just there, now and not just then. Yet by all accounts, scientific, ethnographic, and even autobiographical, they do not. 
Religion avoids the trap of magic. In a religious system, maximizing humans seek to interact with maximizing "gods" - supernatural beings with their own preferences. This makes religion less susceptible to refutation, because failure can be explained in terms of the gods' autonomy and personality. The implications are immense:

Religious practitioners can ask whereas magical practitioners demand: Humans approach the gods as supplicants - listening, petitioning, hoping, and waiting, rather than summoning, compelling, projecting, and manipulating.

Religion can excuse failure while taking credit for success: A priest, pastor, or petitioner can always counter frustration or disappointment with the thought that God did hear and did answer, but the answer was "No."

Religion can focus on the future: The gods are not obligated to deliver on demand or even in this life. They can take their time, promising only that "it shall come to pass" (Isaiah 2:2).

Religion can remain general: The gods can avoid specifics, even as they promise to sustain, nurture, and save.

Religion can refuse tests: Gods can play by their own rules. Thus, the same biblical tradition that scoffs at magicians', applauds the king who tests them, and proclaims its superior efficacy, can nevertheless denounce those who would "test the Lord your God" (Deuteronomy 6:17, see also Daniel 2-3).

Religion can demand sacrifice, whereas magic can only demand technique: The gods can ask things of you as a matter of need, preference, or concern for your own good.

Religion can ask why; magic remains matter-of-fact: Religion can produce systematic theology (though this is certainly more characteristic of Western monotheism than other religious traditions). If only to protect itself against refutation, magic tends to be highly unsystematic.

Religious specialists can work clearly, openly, publicly, and regularly: With all the protections described above, religion has relatively little to hide. It can offer instruction instead of mysterious mumbo-jumbo, and it can regularly meet in public rather than work in secret. Magic centers on one-on-one client-practitioner relationships governed by the customer's sporadic needs and satisfaction with the specific services rendered.

The technology of religion thus serves to promote group activities, intense commitment, long-term relationships, loyalty, exclusivity, contribution-based financing, and collective goods. These, in turn, sustain religion's most important contributions to culture: collective identity, shared values, and individual moral constraint. ${ }^{14}$ 


\section{Acknowledgements}

This work was supported in part by grants from the Mercatus Center at George Mason University and the Project on Religion, Political Economy, and Society at Harvard University. Early versions of this paper were presented at the 2002 Meetings of the European Public Choice Society, and at workshops at George Mason University, the Australian Defence Force Academy, and Marquette University. We are indebted to colleagues at these institutions for their comments and suggestions, and to Charles Rowley and the other participants of the Conference on the Political Economy of Terrorism. 


\section{Notes}

${ }^{1}$ On the rationality of suicide terrorists, see Wintrobe (2003), and Sprinzak (2000).

${ }^{2}$ The economic approach steers a path between the journalistic tendency to over-generalize and overparticularize the causes of contemporary Islamic radicalism. The overly general explanations include those that largely ignore religion and attribute militancy to poverty, oppression, or Western imperialism. Such explanations cannot account for the relative absence of terrorism throughout the poor, non-democratic, and non-Western nations of the world. By contrast, the overly particular explanations emphasize the unique attributes of Muslim culture, Middle-Eastern history, and contemporary politics, economics, and technology. The obvious problem with this approach is its failure to account for religious militancy in other many other times, places, and religious traditions.

${ }^{3}$ Many elements of the theory are present or presaged in the path breaking work of Rodney Stark and William S. Bainbridge $(1980 ; 1987)$.

${ }^{4}$ See, for example, A Celebration of Sex: A Guide to Enjoying God's Gift of Married Sexual Pleasure (Rosenau 2002).

${ }^{5}$ This conclusion contrasts with that of most early-to-mid twentieth-century sociologists and anthropologists, who sought to define, explain, and analyze religion in terms of its supposed functions, most notably social integration (e.g., Durkheim, Radcliffe-Brown, Malinowski, Parsons, and Yinger).

${ }^{6}$ Diversification through limited involvement in a variety of different supernatural activities is yet another risk-reducing strategy common among consumers of magic. As Iannaccone (1995) demonstrates, however, religious institutions must limit diversification to avoid free riding.

${ }^{7}$ Even when secular legal systems are quite efficient we sometimes see religious sects organizing private arbitration, as is the case for Ultra-Orthodox Jews and Jaynes in global diamond exchanges (Richman 2005).

${ }^{8}$ Christoph Reuter's (Reuter 2004, pp. 76-77) account of Hezbollah's behavior at a public rally immediately following Israel's May 2000 pullout from southern Lebanon is telling: "Everyone expected [Hezbollah's Secretary-General, Sheik Nasrallah] to announce that he now wanted to take the battle to Jerusalem. Instead, Nasrallah talked about roads, schools, hospitals; about prudence and reconstructions; about infrastructure measures and the power supply ... the Hezbollah leadership deliberately pulled back from talk of total war to demonstrate its concern for the social welfare of the people."

${ }^{9}$ Theology is also invoked to explain why suicide bombers usually target members of other religions, whereas insurgents routinely attack coreligionists. Berman and Laitin (2005) argue that this difference is the product of pragmatism rather than ideology. Suicide attacks are rationally reserved for "hard" targets, which cannot be destroyed without very high risk of death or capture. Insurgents often kill coreligionists, but seldom do so via suicide attacks because coreligionists are generally "soft" targets because they live among them. Thus most fatal Palestinian attacks on Israelis living within the "green" line (of Israel proper) are suicide attacks, whereas most fatal Palestinian attacks on Israelis in the West Bank and Gaza do not involve suicide.

${ }^{10}$ In a sense, we also part company with Ekelund et al. (1996) who interpret actions of the medieval Catholic Church strictly in terms of the material/economic interests of church leaders who are viewed as the management of a massive, rent-seeking monopoly. This interpretative framework may have much to say about the actions of the Catholic Church at the height of its temporal power, and by extension to other large, hierarchical churches with strong ties to government, but it is of limited relevance for the loose networks typical of sects, most of which do not even distinguish between clergy and laity. Sect leaders 
may have utility functions identical to those of other church leaders (or to those of corporate CEOs), but the club-like character of most sects limits their capacity to amass wealth and impedes the systematic distribution of wealth to a hierarchy of subordinates. "Profit maximization" poorly describes the sectarian "firm" that collectively transforms numerous activities and inputs into an equally numerous collection of outputs - most of which are directly consumed by the worker-members, rather than sold for money or exchanged for other goods and services. According to Marc Sageman who has mapped militant Islamist networks more thoroughly than anyone else, "the global Salafi jihad consists of four major clusters surrounded by innumerable islands consisting of cliques and singletons of potential candidates" (2004, p. 171). Although some subunits are hierarchical, the overall structure is informal and decentralized, with multiple alliances among separate organizations.

${ }^{11}$ Carrying this insight forward to the present, the most striking feature of contemporary American sects may well be their near total lack of militancy. Despite unflinching attachment to what they perceive as absolute and exclusive "truth," the Jehovah's Witnesses, Mormons, and Adventists, and virtually all other American-born sects display strong commitment to religious toleration. Indeed, talk of the fanaticism, intolerance, and militancy of the "Christian right" strikes me as overblown, unwarranted, and misleading effective rhetoric, but very bad scholarship. Even Jerry Falwell's Moral Majority and Pat Robertson's Christian Coalition, the most politically aggressive organizations within evangelical Protestantism, have engaged in less civil disobedience than religious liberals did in the 1960's Civil Rights era (and far less violence than did the left-wing radicals of the same period). Conservative evangelicals may indeed scare liberal Americans (and surveys leave no doubt that most academics and journalists are very liberal), but the threat remains democratic, nonviolent, and conventional - the product of grass-roots political organization and mainstream voter support.

${ }^{12}$ Although we continue to encounter anecdotal reports that many suicide-bombers are poor, young, and ignorant volunteers, with little or no history of involvement in the organizations who engineer their "martyrdom," more careful studies argue otherwise. Berrebi (2003) found that Palestinian suicide bombers have substantially more schooling and better economic backgrounds than the average Palestinian. Berrebi's statistical portrait reaffirms the case-based portrait that emerges from Nassra Hassan's (2001) interviews with potential Palestinian suicide-bombers, which in turn sounds exactly like a quote from the literature on cult converts: "None of [the bombers] were uneducated, desperately poor, simple minded or depressed. Many were middle class and, unless they were fugitives, held paying jobs. ... Two were the son's of millionaires." See also Marc Sageman(2004, p. 97), a forensic psychiatrist and foreign service office who has compiled extensive biographies on 172 Islamic jihadists. Sageman concludes that "almost nothing in the data challenges the rational actor theory ... the members studied did not come from poor backgrounds ... their education was modern ... they did not seem to display any psychiatric pathology."

${ }^{13}$ Magical elements are, to varying degrees, present in all religious traditions. Medieval Catholicism, with its emphasis on miracles, saints, and relics, was considerably more magical than Reformation Protestantism, which emphasized faith and Biblical teaching above all else. Reform Judaism is considerably less magical than Hassidic Judaism.

${ }^{14}$ This conclusion recapitulates Durkheim's (1965, pp. 59, 44-45) famous observations contrasting religion and magic, which went so far as to define religion in terms of its collective dimension. According to Durkheim, "In all history we do not find a single religion without a Church ... It is quite another matter with magic ... The magician has a clientele and not a Church ... A Church ... is a moral community ... But Magic lacks any such community." 


\section{References}

Becker, G. S. (1976). The Economic Approach to Human Behavior. University of Chicago Press: Chicago.

Berman, E. (2000). Sect, Subsidy and Sacrifice: An Economist's View of Ultra-Orthodox Jews. Quarterly Journal of Economics. 115(3): 905-953.

Berman, E. (2003). Hamas, Taliban and the Jewish Underground: An Economist's View of Radical Religious Militias. NBER Working Paper, No. w10004.

Berman, E., \& Laitin, D. D. (2005). Hard Targets: Theory and Evidence on Suicide Attacks. UC San Diego, mimeo.

Berrebi, C. (2003). Evidence About the Link Between Education, Poverty and Terrorism Among Palestinians. Princeton University

Bock, E. W., Cochran, J. K., \& Beeghly, L. (1987). Moral Messages: The Relative Influence of Denomination on the Religiosity-Alcohol Relationship. The Sociological Quarterly. 28(1): 89-103.

Chen, D. (2003). Economic Distress and Religious Intensity: Evidence from Islamic Resurgence During the Indonesian Financial Crisis. MIT, mimeo.

Chen, D. (2004). Club Goods and Group Identity: Evidence from Islamic Resurgence During the Indonesian Financial Crisis. MIT, mimeo.

Darby, M. R., \& Karni, E. (1973). Free Competition and the Optimal Amount of Fraud. Journal of Law and Economics. 16(1): 67-88.

Durkheim, E. (1965). The Elementary Forms of the Religious Life. Free Press: New York, NY.

Ekelund, R. B., Hébert, R. F., Tollison, R. D., Anderson, G. M., \& Davidson, A. B. (1996). Sacred Trust: The Medieval Church as an Economic Firm. Oxford University Press: New York, NY.

Ellison, C. G. (1991). Religious Involvement and Subjective Well-Being. Journal of Health and Social Behavior. 32(1): 80-99.

Ellison, C. G. (1993). Religion, the Life Stress Paradigm, and the Study of Depression. In J.S. Levin (ed.), Religion in Aging and Mental Health. 78-121. Sage: Thousand Oaks, CA.

Filatov, S. (1993). On Paradoxes of the Post-Communist Russian Orthodox Church. In R. Cipriani (ed.), Religions San Frontiers? Present and Future Trends of Migration, Culture, and Communication. 117-125. Rome University: Rome.

Finke, R., \& Stark, R. (1992). The Churching of America, 1776-1990: Winners and Losers in Our Religious Economy. Rutgers University Press: New Brunswick, NJ.

Fritsch, P. (2001). Religious Schools in Pakistan Fill Void -- and Spawn Warriors, Wall Street Journal. A1, A24.

Greeley, A. M. (1989). Religious Change in America. Harvard University Press: Cambridge, MA.

Hadden, J. K. (1987). Toward Desacralizing Secularization Theory. Social Forces. 65(3): 587-611.

Hassan, N. (2001). An Arsenal of Believers, New Yorker. 36-41.

Hume, D. (1989). Of Superstition and Enthusiasm. Essays: Moral, Political and Literary. 73-79. LibertyClassics. 
Iannaccone, L. R. (1988). A Formal Model of Church and Sect. American Journal of Sociology. 9(Supplement): s241-s268.

Iannaccone, L. R. (1992). Sacrifice and Stigma: Reducing Free-Riding in Cults, Communes, and Other Collectives. Journal of Political Economy. 100(2): 271292.

Iannaccone, L. R. (1994). Why Strict Churches are Strong. American Journal of Sociology. 99(5): 1180-1211.

Iannaccone, L. R. (1995). Religion, Values, and Behavior Constraint.

Iannaccone, L. R. (1995). Risk, Rationality, and Religious Portfolios. Economic Inquiry. 38(2): 285-295.

Iannaccone, L. R. (1998). An Introduction to the Economics of Religion. Journal of Economic Literature.

Jagodzinski, W., \& Greeley, A. M. (1997). The Demand for Religion: Hard Core Atheism and 'Supply Side' Theory.

Kanter, R. M. (1973). Commitment and Community: Communes and Utopias in Sociological Perspective. Harvard University Press: Cambridge.

Krueger, A. B., \& Maleckova, J. (2003). Education, Poverty and Terrorism: Is There a Causal Connection? Journal of Economic Perspectives. 17(4).

Lehrer, E. L., \& Chiswick, C. U. (1993). Religion as a Determinant of Marital Stability. Demography. 30(3): 385-404.

Marty, M. E., \& Appleby, R. S., Eds. (1991). Fundamentalism Observed. Chicago: University of Chicago Press.

Mishal, S., \& Sela, A. (2000). The Palestinian Hamas : vision, violence, and coexistence. Columbia University Press: New York.

Munson, Z. (2002). Social Movement Theory and the Egyptian Muslim Brotherhood. Sociological Quarterly. 42(2).

Pascal, B. (1910). Pascal's Pensees.

Rashid, A. (2002). Jihad : the rise of militant Islam in Central Asia. Yale University Press: New Haven.

Reuter, C. (2004). My life is a weapon : a modern history of suicide bombing. Princeton University Press: Princeton, NJ.

Richman, B. D. (2005). How Communities Create Economic Advantage: Jewish Diamond Merchants in New York. Duke Law School Legal Studies Research Paper No. 65; Harvard Law and Economics Discussion Paper No. 384. http://ssrn.com/abstract $=349040$

Rosenau, D. (2002). A celebration of sex: a guide to enjoying God's gift of sexual intimacy. Thomas Nelson: Nashville.

Sageman, M. (2004). Understanding terror networks. University of Pennsylvania Press: Philadelphia.

Schiff, Z., Yaari, E., \& Friedman, I. (1990). Intifada : the Palestinian uprising--Israel's third front. Simon and Schuster: New York.

Smith, A. (1965). An Inquiry into the Nature and Causes of The Wealth of Nations. Modern Library: New York.

Sprinzak, E. (2000). Rational Fanatics. Foreign Policy. September/October.

Stark, R., \& Bainbridge, W. S. (1980). Towards a Theory of Religion: Religious Commitment. Journal for the Scientific Study of Religion. 19(2): 114-128. 
Stark, R., \& Bainbridge, W. S. (1985). The Future of Religion. University of California Press: Berkeley.

Stark, R., \& Bainbridge, W. S. (1987). A Theory of Religion. Peter Lang Publishing: Bern.

Stark, R., \& Bainbridge, W. S. (1998). Religion, Deviance, and Social Control. Routledge: New York, NY.

Stark, R., Iannaccone, L. R., \& Finke, R. (1996). Religion, Science, and Rationality. American Economic Review Papers and Proceedings. 86(2): 433-37.

Troeltsch, E. (1931). The Social Teaching of the Christian Churches. Macmillan: New York.

Troyanovsky, I., Ed. (1991). Religion in the Soviet Republics. San Francisco: HarperCollins.

Warner, R. S. (1993). Work in Progress Toward a New Paradigm in the Sociology of Religion. American Journal of Sociology. 98(5): 1044-1093.

Weber, M. (1963). The Sociology of Religion. Beacon Press: Boston.

Wintrobe, R. (2003). Can suicide bombers be rational? University of Western Ontario 